\title{
JNPH
}

Volume 7 No. 1 (April 2019)

(C) The Author(s) 2019

\section{EFEKTIVITAS PENAMBAHAN MIKROORGANISME LOKAL (MOL) BUAH MAJA SEBAGAI AKTIVATOR DALAM PEMBUATAN KOMPOS}

\section{EFFECTIVENESS OF ADDITIONAL LOCAL MICROORGANISM (MOL) FRUITS MAJA AS ACTIVATORS IN COMPOSITE MAKING}

\author{
ULLYA RAHMAWATI, MELY GUSTINA, HAIDINA ALI, \\ RAMADANIATI KHOIRUL ISMI \\ POLITEKNIK KESEHATAN KEMENTRIAN KESEHATAN BENGKULU \\ PRODI D III KESEHATAN LINGKUNGAN \\ JURUSAN KESEHATAN LINGKUNGAN
}

\begin{abstract}
ABSTRAK
Penumpukan sampah organik serta proses pengolahan kompos secara konvensional yang membutuhkan waktu lama dan tidak efektif, sehingga perlu dicari alternatif pemecah masalah dengan cara menemukan suatu bahan yang berfungsi sebagai aktivator dalam pengomposan sehingga dapat mempercepat waktu pengomposan. Tujuan penelitian adalah Untuk mengetahui efektifitas MOL buah maja sebagai aktivator dalam pembuatan kompos. Jenis penelitian True Eksperimen dengan menggunakan rancangan posttest only with control group design, dengan penambahan mikroorganisme lokal (MOL) buah maja $20 \mathrm{ml}, 25 \mathrm{ml}$, dan $30 \mathrm{ml}$. Analisis data dengan menggunakan uji One Way Anova yang dilanjutkan dengan Uji Bonferroni. Ada perbedaan lama waktu terbentuknya kompos dengan penambahan larutan MOL buah maja dengan dosis $20 \mathrm{ml}, 25 \mathrm{ml}$, dan $30 \mathrm{ml}$. Diharapkan bagi masyarakat dapat mengelola sampah organik dengan memanfaatkan Mikroorganisme Lokal (MOL) buah maja sebagai aktivator untuk mempercepat proses pengomposan.
\end{abstract}

Kata Kunci: Kompos, Mikroorganisme Lokal, Buah Maja

\begin{abstract}
The accumulation of organic waste and conventional composting process that takes a long time and was not effective, so need to find alternative problem solvers by finding a material that serves as an activator in composting so as to accelerate the composting time. The purpose of this study was to determine the effectiveness of MOL Maja fruit as an activator in composting. Type of True Experimental research using posttest only control group design, with the addition of local microorganisms (MOL) of Maja fruit $20 \mathrm{ml}, 25 \mathrm{ml}$, and $30 \mathrm{ml}$. Data analysis using One Way Anova test followed by Bonferroni Test. There was a difference in the time of composting with the addition of MOL solution, Maja fruit with doses of $20 \mathrm{ml}, 25 \mathrm{ml}$, and $30 \mathrm{ml}$. It was expected that the community can manage organic waste by utilizing Maja Microorganisms (MOL) as activators to accelerate the composting process.
\end{abstract}

Keywords: Compost, Local Microorganism, Maja Fruit 


\section{PENDAHULUAN}

Menurut Kementerian Lingkungan Hidup dan Kehutanan, pertambahan jumlah penduduk berbanding lurus dengan jumlah sampah yang dihasilkan, dengan jumlah penduduk Indonesia saat ini 250 juta orang, jika setiap orang menghasilkan sampah 0,7 $\mathrm{kg} /$ hari, maka timbunan sampah secara nasional mencapai $175 \mathrm{ribu}$ ton/hari atau setara dengan 64 juta ton/tahun. Tingkat timbulan sampah di Kota Bengkulu sebanyak $3 \mathrm{~m}^{3} /$ hari, dengan jumlah penduduk 360.772 jiwa, menghasilkan $1.082,32 \mathrm{~m} 3 / \mathrm{hr}$ timbulan sampah. Jumlah ini didapatkan dari jumlah penduduk dikalikan $3 / 1000\left(\mathrm{~m}^{3} / \mathrm{hr}\right)$. Namun Kota Bengkulu baru dapat mengelola sebanyak $66,90 \mathrm{~m}^{3} / \mathrm{hr}$. Sehingga banyaknya sampah yang belum terlayani adalah 1.015,42 $\mathrm{m}^{3} / \mathrm{hr}$ (Dinas Kebersihan Kota Bengkulu, 2016).

Masyarakat pada umumnya mengurangi sampah seperti sisa-sisa makanan, plastik, kertas, botol dan lain-lain dengan cara membakarnya atau membuangnya langsung ke selokan dan tempat pembuangan sampah sementara. Sampah erat kaitannya dengan kesehatan masyarakat,karena dari sampah tersebut akan hidup berbagai mikroorganisme penyebab penyakit (bakteri pathogen), dan juga binatang serangga sebagai pemindah/penyebar penyakit (vector). Oleh sebab itu sampah harus dikelola dengan baik sampai sekecil mungkin tidak mengganggu atau mengancam kesehatan masyarakat. Pengelolaan sampah yang baik, bukan untuk kepentingan kesehatan saja, tetapi juga untuk keindahan lingkungan. Pengelolaan sampah meliputi pengumpulan, pengangkutan, memusnahkan sampah dengan jalan membakar didalam tungku pembakaran (incinerator), dan pengolahan sampah menjadi pupuk (kompos).

Pengomposan adalah proses dimana bahan organik mengalami penguraian secara biologis, khususnya oleh mikroba-mikroba yang memanfaatkan bahan organik sebagai sumber energi. Membuat kompos adalah mengatur dan mengontrol prose salami tersebut agar kompos dapat terbentuk lebih cepat. Proses ini meliputi membuat campuran bahan yang seimbang, pemberian air yang cukup, mengatur aerasi, dan penambahan aktivator pengomposan (Alex, 2015).

Lama waktu pengomposan tergantung pada karakteristik bahan yang dikomposkan, metode yang pengomposan yang dipergunakan dan dengan atau tanpa penambahan aktivator pengomposan. Secara alami pengomposan akan berlangsung dalam waktu beberapa minggu atau 2 tahun hingga kompos benar-benar matang (Alex, 2015).

Larutan MOL (Mikroorganisme Lokal) merupakan larutan hasil fermentasi yang berbahan dasar dari berbagai sumber daya yang tersedia di alam seperti bonggol pisang, maja, lamtoro. MOL Maja mengandung unsur-unsur makro dan mikro yang dibutuhkan untuk mendukung pertumbuhan vegetatif, perkembangan dan kesehatan. Unsur-unsur makro tersebut antara lain nitrogen, fosfor, kalium, karbon serta unsur hara mikro antara lain magnesium dan besi (Syaifudin, dkk, 2010).

Buah maja (Aegle marmelos) merupakan salah satu contoh tanaman yang keberadaannya kurang dipedulikan, masyarakat sekitar juga tidak memanfaatkan buah maja, padahal buah ini memiliki banyak manfaat misalnya mengandung nitrogen tinggi, dan memiliki zat pengatur tumbuh baik untuk tanaman (Rismayani, 2013).

Buah maja merupakan tanaman dari family Rutaceae, yang penyebarannya tumbuh di dataran rendah hingga ketinggian \pm $500 \mathrm{~m}$ dpl. Tumbuhan ini terdapat di Negara Asia Selatan dan Asia Tenggara termasuk di Indonesia. Pohon maja mampu tumbuh di lahan basah seperti rawa-rawa maupun di lahan kering dan ekstrim, pada suhu $49^{0} \mathrm{C}$ $\begin{array}{lllll}\text { pada musim kemarau hingga } & -70 & { }^{0} \mathrm{C}\end{array}$ (Rismayani, 2013).

Untuk mengatasi masalah penumpukan sampah organik serta proses pengolahan kompos secara konvensional yang membutuhkan waktu lama dan tidak efektif, sehingga perlu dicari alternatif pemecah masalah dengan cara menemukan suatu bahan 
yang berfungsi sebagai aktivator dalam pengomposan sehingga dapat mempercepat waktu pengomposan. Bahan aktivator tersebut antara lain adalah mikroorganisme lokal dari buah maja. Untuk itu peneliti tertarik melakukan penelitian berjudul "Efektifitas Penambahan MOL Buah Maja Sebagai Bahan Aktifator dalam Pembuatan Kompos".

\section{METODE PENELITIAN}

Jenis penelitian yang dilakukan merupakan True Eksperimen dengan menggunakan rancangan posttest only with control group design, yaitu kelompok kontrol dan kelompok perlakuan. Penelitian ini dilaksanakan diworkshop Kesehatan Lingkungan Poltekkes Kemenkes Bengkulu. Waktu Penelitian ini dilaksanakan pada bulan Maret s/d Mei 2017. Analisis yang digunakan yaitu Analisis univariat, bivariat dengan menggunakan uji One Way Anova yang dilanjutkan dengan Uji Bonferroni untuk melihat perbedaan efektifitas Mikroorganisme Lokal (MOL) buah maja terhadap lama waktu terbentuknya kompos.

Alat dan bahan yang digunakan dalam penelitian ini yaitu Botol plastic, pisau, ember, sendok pengaduk, polybag, pipa PVC, alat tulis, timbangan dan botol ukur. Bahan yang digunakan dalam pembuatan MOL: Buah maja 200 gr, Bekas Air cucian beras/air leri $500 \mathrm{ml}$, Gula merah 40 gr. Bahan pembuatan kompos: sampah organik pasar sebanyak $40 \mathrm{~kg}$, jerami $10 \mathrm{~kg}$, dan sekam padi $10 \mathrm{~kg}$.

Pembuatan MOL dengan cara belah buah maja ambil bagian dalamnya remas-remas buah maja sebanyak 200 gr, haluskan gula merah 40 gr aduk dengan buah maja, masukan air bekas cucian beras $500 \mathrm{ml}$, tutup rapat dengan kertas koran, ikat koran agar tidak terlepas, setelah 15 hari Mol sudah bisa digunakan. Pembuatan MOL berhasil jika sudah keluar bau alkohol, perubahan warna air menjadi kuning, terdapat busa putih yang mengapung.

Pembuatan kompos langkah pertama yaitu menyiapkan bahan yang diperlukan, yaitu sampah sayuran, jerami, dan sekam padi. Sampah sayuran hijau dipotong-potong dengan ukuran 2-5 cm. campurkan bahan tersebut menjadi satu hingga rata. Menyiapkan polybag sejumlah 20 buah dengan perincian sebagai berikut: 15 kelompok untuk perlakuan penambahahn aktifator MOL sebanyak $20 \mathrm{ml}, 25 \mathrm{ml}$, dan $30 \mathrm{ml}$ dan 5 kelompok kontrol tanpa diberi perlakuan, masukkan sampah organik yang telah dicampur rata untuk masing-masing kedalam polybag sebanyak $3 \mathrm{~kg}$. Semprotkan aktifator MOL sebanyak $20 \mathrm{ml}, 25 \mathrm{ml}$, dan $30 \mathrm{ml}$ ke 15 kelompok perlakuan. Masukkan pipa yang telah diberi lubang. Selanjutnya polybag diikat dengan tali. Untuk mempertahankan suhu maka setiap 3 hari sekali diaduk sehingga tidak terlalu panas. Kemudian lakukan pengamatan dan pengukuran $\mathrm{pH}$, temperatur, bentuk fisik, bau dan warna setiap hari. Apabila kompos sudah memenuhi kriteria kompos matang dengan cirri-ciri berbentuk butiran-butiran kecil seperti tanah, bau tanah dan coklat kehitaman maka dapat dinyatakan kompos telah matang.

\section{HASIL}

\section{ANALISIS UNIVARIAT}

Analisis univariat bertujuan menggambarkan distribusi rata-rata masingmasing variabel yang dianalisis secara statistik deskriptif (mean dan standar deviasi), disajikan dalam bentuk table dan distribusi rata-rata untuk mengetahui populasi masingmasing variabel.

\section{Tabel 1 Distribusi Lama Waktu Pengomposan Pada Kelompok Kontrol Dan Perlakuan}

\begin{tabular}{|c|c|c|c|c|}
\hline \multirow[t]{2}{*}{ Pengulangan } & \multicolumn{4}{|c|}{$\begin{array}{c}\text { Lama Waktu Terbentuknya Kompos } \\
\text { (Hari) }\end{array}$} \\
\hline & $20 \mathrm{ml}$ & $25 \mathrm{ml}$ & $30 \mathrm{ml}$ & kontrol \\
\hline 1 & 28 & 24 & 20 & 33 \\
\hline 2 & 27 & 24 & 21 & 33 \\
\hline 3 & 26 & 23 & 19 & 32 \\
\hline 4 & 27 & 24 & 19 & 32 \\
\hline
\end{tabular}




\begin{tabular}{ccccc}
\hline 5 & 26 & 23 & 20 & 33 \\
\hline jumlah & 134 & 118 & 99 & 163 \\
\hline rata-rata & 27 & 24 & 20 & 33 \\
\hline
\end{tabular}

Berdasarkan tabel 1 distribusi lama waktu pengomposan pada kelompok kontrol dan perlakuan pengomposan sampah organik. Rata-rata lama waktu terbentuknya kompos pada kelompok kontrol yaitu 33 hari, rata-rata lama waktu terbentuknya kompos pada penambahan $20 \mathrm{ml}$ yaitu 27 hari, rata-rata lama waktu terbentuknya kompos pada penambahan $25 \mathrm{ml}$ yaitu 24 hari, dan rata-rata lama waktu terbentuknya kompos pada penambahan $30 \mathrm{ml}$ yaitu 20 hari.

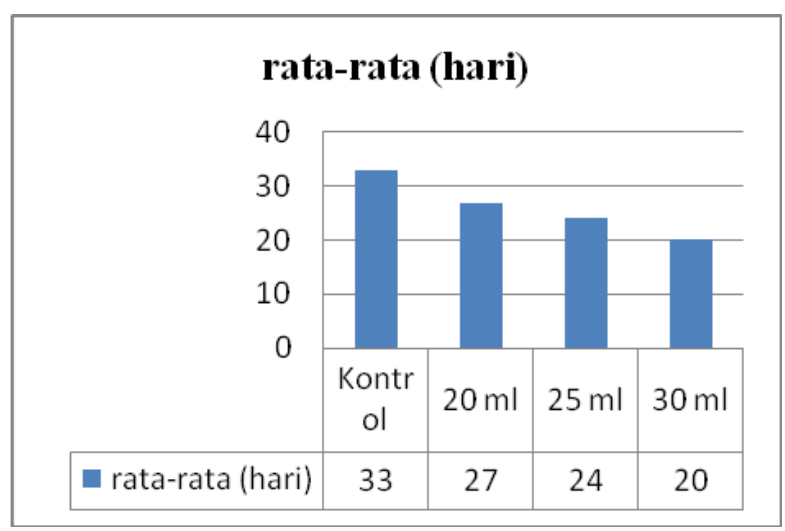

\section{Grafik 1 Rata-rata Lama Waktu Pengomposan Pada Kelompok Kontrol Dan Perlakuan}

Berdasarkan grafik 1 rata-rata lama waktu pengomposan pada kelompok kontrol dan perlakuan pengomposan sampah organik. Waktu yang paling efektif dalam terbentuknya kompos yaitu pada kelompok penambahan aktifator MOL buah maja dengan dosis $30 \mathrm{ml}$ dengan lama waktu 20 hari.

\section{ANALISIS BIVARIAT}

Tabel 2 Hasil Uji One Way Anova Lama Waktu (Hari) Pengomposan Sampah Organik Kelompok Perlakuan Dan Kontrol

\begin{tabular}{|c|c|c|c|c|c|}
\hline \multirow{2}{*}{$\begin{array}{c}\begin{array}{c}\text { Variabel } \\
\text { Perlakuan }\end{array} \\
\text { Kontrol }\end{array}$} & \multirow{2}{*}{ 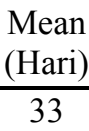 } & \multirow{2}{*}{$\begin{array}{c}\text { SD } \\
0.548\end{array}$} & \multicolumn{2}{|c|}{$95 \% \mathrm{Cl}$} & \multirow[t]{2}{*}{ P Value } \\
\hline & & & 31,92 & 33,28 & \\
\hline $\begin{array}{c}\text { Penambahan } \\
\text { Mol Maja } \\
\text { 20ml }\end{array}$ & 27 & 0.837 & 25,76 & 27,84 & 0,000 \\
\hline $\begin{array}{c}\text { Penambahan } \\
\text { Mol Maja } 25 \\
\text { ml }\end{array}$ & 24 & 0.548 & 22,92 & 24,28 & \\
\hline $\begin{array}{c}\text { Penambahan } \\
\text { Mol Maja } 30 \\
\text { ml }\end{array}$ & 20 & 0.837 & 18,76 & 20,84 & \\
\hline
\end{tabular}

Tabel 2 menunjukkan bahwa rata-rata lama waktu terbntuknya kompos pada penambahan MOL sebanyak $30 \mathrm{ml}$ adalah 20 . Hasil uji statistik didapat nilai $\rho=0,000<\alpha$ $(0,05)$, berarti dapat disimpulkan ada perbedaan lama waktu terbentuknya kompos dengan penambahan larutan MOL buah maja dengan dosis $20 \mathrm{ml}, 25 \mathrm{ml}$, dan $30 \mathrm{ml}$. Untuk mengetahui selisih rat-rata beda lama waktu terbentuknya kompos dari ketiga perlakuan dengan penamabahan MOL buah maja $20 \mathrm{ml}, 25 \mathrm{ml}$, dan $30 \mathrm{ml}$ dilakukan dengan uji Benferroni. Hasil uji tersebut dapat dilihat sebagai berikut:

Tabel 3 Hasil Uji Bonferroni Perbedaan Lama Waktu (Hari) Pengomposan dengan Menggunakan Penambahan Mikro Organisme Lokal (MOL) Buah Maja Dengan Variasi Dosis $20 \mathrm{ml}, 25 \mathrm{ml}$ dan 30 ml

\begin{tabular}{cccc}
\hline \multicolumn{2}{c}{ Perlakuan } & $\begin{array}{c}\text { rata-rata beda } \\
\text { (hari) }\end{array}$ & $\rho$ value \\
\hline \multirow{3}{*}{ kontrol } & $20 \mathrm{ml}$ & 5.800 & 0.000 \\
\cline { 2 - 4 } & $25 \mathrm{ml}$ & 9.000 & 0.000 \\
\cline { 2 - 4 } & $30 \mathrm{ml}$ & 12.800 & 0.000 \\
\hline $20 \mathrm{ml}$ & $25 \mathrm{ml}$ & 3.200 & 0.000 \\
\cline { 2 - 4 } & $30 \mathrm{ml}$ & 7.000 & 0.000 \\
\hline $25 \mathrm{ml}$ & $30 \mathrm{ml}$ & 3.800 & 0.000 \\
\hline
\end{tabular}

Tabel 3 Menunjukkan bahwa ada selisih rata- rata beda lama waktu terbentuknya kompos dengan penambahan larutan MOL dosis $20 \mathrm{ml}, 25 \mathrm{ml}$ dan $30 \mathrm{ml}$. Dari data tersebut dapat disimpulkan bahwa dosis penambahan larutan MOL yang paling efektif 
adalah dosis $30 \mathrm{ml}$.

\section{PEMBAHASAN}

Hasil penelitian efektifitas Mikroorganisme Lokal (MOL) buah maja terhadap lama waktu terbentuknya kompos diperoleh rata-rata waktu pengomposan pada kelompok kontrol yaitu 33 hari. Pada kelompok penambahan MOL dengan dosis 20 $\mathrm{ml}$ rata-rata waktu pengomposannya yaitu 27 hari. Pada kelompok penambahan MOL dengan dosis $25 \mathrm{ml}$ rata-rata waktu pengomposannya yaitu 24 hari, dan pada kelompok penambahan MOL dengan dosis 30 $\mathrm{ml}$ rata-rata waktu pengomposannya yaitu 20 hari.

Hasil bivariat juga menunjukkan bahwa penambahan aktifator Mikroorganisme Lokal (MOL) buah maja dengan dosis $20 \mathrm{ml}, 25 \mathrm{ml}$, dan $30 \mathrm{ml}$ memiliki kemampuan untuk mempercepat waktu pengomposan sampah organik. Dalam hal ini dapat dilihat dari $\rho=<$ 0,05 yang berarti Ho ditolak dan Ha diterima.

Uji lanjut Benferroni juga dilakukan untuk mengetahui selisih rata- rata beda lama waktu terbentuknya kompos dengan penambahan larutan MOL dosis $20 \mathrm{ml}, 25 \mathrm{ml}$ dan $30 \mathrm{ml}$. Pada kelompok penambahan MOL dengan dosis $20 \mathrm{ml}$ lama waktu pengomposannya yaitu 27 hari.Pada kelompok penambahan MOL dengan dosis 25 $\mathrm{ml}$ lama waktu pengomposannya yaitu 24 hari dan pada kelompok penambahan MOL dengan dosis $30 \mathrm{ml}$ lama waktu pengomposannya yaitu 20 hari. Berdasarkan data tersebut dapat disimpulkan bahwa dosis penambahan larutan MOL yang paling efektif adalah dosis $30 \mathrm{ml}$.

Pengukuran bentuk fisik, bau, dan warna menunjukan bahwa keadaan awal bahan kompos secara fisik berbentuk potonganpotongan kecil seperti sampah dan bewarna hijau. Keadaan ini akan mengalami perubahan selama proses pengomposan berlangsung. Bentuk fisik dari potonganpotongan kecil mulai hancur hingga menjadi seperti tanah, begitu pula bau dan warna kompos mengalami perubahan yaitu bahan kompos dari berbau sampah menjadi berbau seperti tanah dan warna berubah dari warna hijau, hitam kecoklatan dan akhirnya berwarna seperti tanah.

Ditinjau dari keadaan tersebut bahwa aktivator mol maja dapat mempercepat proses pengomposan khususnya pada kelompok perlakuan dengan dosis $30 \mathrm{ml}$ dengan lama waktu pengomposan 20 hari dibandingkan dengan kontrol dan kelompok perlakuan lainnya yakni penambahan mol maja $25 \mathrm{ml}$ dan $30 \mathrm{ml}$. dengan demikian semakin banyak mikroorganisme yang ada dalam bahan kompos maka akan semakin cepat dalam mendomposisi sampah organik, sehingga akan mempersingkat waktu pengomposan sampah organik.

\section{KESIMPULAN}

Berdasarkan hasil penelitian dengan judul "Efektifitas Penambahan Mokroorganisme Lokal (MOL) Buah Maja Sebagai Aktivator dalam Pembuatan Kompos" dapat disimpulkan bahwa:

Distribusi lama waktu terbentuknya kompos dengan penambahan larutan MOL buah maja dengan dosis $20 \mathrm{ml}, 25 \mathrm{ml}$, dan 30 $\mathrm{ml}$. Rata-rata lama waktu terbentuknya kompos dengan penambahan mikroorganisme lokal (MOL) buah maja $20 \mathrm{ml}$ yaitu 27 hari. Rata-rata lama waktu terbentuknya kompos dengan penambahan mikroorganisme lokal (MOL) buah maja $25 \mathrm{ml}$ yaitu 24 hari. Ratarata lama waktu terbentuknya kompos dengan penambahan mikroorganisme lokal (MOL) buah maja $30 \mathrm{ml}$ yaitu 20 hari.

Penambahan mikroorganisme lokal (MOL) buah maja sebanyak $30 \mathrm{ml}$ lebih efektif dibandingkan dengan penggunaan variasi dosis $20 \mathrm{ml}$ dan $25 \mathrm{ml}$ dalam mempercepat waktu pengomposan sampah organik.

\section{SARAN}

1. Bagi Akademik

Bagi akademik diharapkan hasil penelitian ini dapat dijadikan literature 
dalam pembelajaran akademik

khususnya bagi Jurusan Kesehatan

Lingkungan.

2. Bagi Masyarakat

Masyarakat dapat mengelola sampah organik dengan memanfaatkan mikroorganisme lokal (MOL) buah maja sebagai aktivator untuk mempercepat proses pengomposan.

3. Bagi Peneliti Lanjutan

Dapat melakuakan penelitian dengan membandingkan aktivator mikroorganisme (MOL) buah maja dengan komposter lainnya

\section{DAFTAR PUSTAKA}

Alex S. 2015. Sukses Mengolah Sampah Organik menjadi pupuk Organik. Pustaka Baru Press: Yogyakarta.

Rismayani. 2013. Manfaat Buah Maja Sebagai Pestisida Nabati untuk Hama Pengerek Buah Kakao (Conomorpha cramerella). Warta Penelitian dan Pengembangan Tanaman Industri, vol.19, No.3.

Syaifudin, A., L. Mulyani., dan E. Sulastri. 2010. Pemberdayaan Mikroorganisme Lokal Sebagai Upaya Peningkatan Kemandirian Petani. Karya Tulis. 